JCGIRM Journal of Corporate Governance, Insurance, and Risk Management (JCGIRM) 2014, Volume 1, Series 2

Pages 210-230

\title{
KEY DRIVERS INFLUENCING SHOPPING BEHAVIOR IN RETAIL STORE
}

\author{
Aamir Hasan ${ }^{\mathrm{a}, *}$, Subhash Mishrab \\ ${ }^{a}$ Gyan Institute of Management and Technology \\ ${ }^{\mathrm{b}}$ Gyan Institute of Management and Technology
}

\begin{abstract}
A B S T R A C T
The purpose of the study was to determine the key drivers which influence the shopping behavior of the customers in the retail store. In today's competitive world with increasing number of retail stores, the retailers need to be more customer oriented. Retail has changed and expanded in all lines of business, be it apparel, jewelry, footwear, groceries.etc. The modern consumer is posing a challenging task for the Indian retailer. More aware, more confident and much more demanding, therefore the retailers are looking for ways to deliver better consumer value and to increase consumer purchase intention. Retailers tend to differentiate themselves by making their service easier to consumers. The study aims to study the key drivers that can influence shopping behavior in retail store. A survey (store intercept) method was employed to elicit primary information from 300 shoppers in different formats of retail stores of Lucknow. The findings reveal the factors that play a greater role in influencing the shopping behavior of customers in retail store. As such, a survey of retail store customer's attitude towards reduced price, sales promotion, quality of the products, proximity to the home, customer service, store atmospherics were analyzed to identify the key drivers influencing shopping behavior in retail store. A questionnaire based on a five-item Likert scale, as well as random sampling, was employed for data collection. Data analysis was accomplished using SPSS software. The paper has found shopping experience, store image and value for money as three important variable out of which shopping experience emerged as a dominant factor which influences the consumer's shopping behavior in the retail store. Since the research has established empirical evidences in determining the key drivers which influences the shopping behavior of the customers in the retail store, it serves as a foundation for a deeper probe into the shopping behavior of the customers in the retail store research domain in the Indian context
\end{abstract}

\section{A R T I C L E I N F O}

Keywords:

\section{Retailing,}

Customers,

\section{Shopping Behavior}

* Corresponding author:

Aamirhasan_1@yahoo.co.in

(Aamir Hasan)

Article Submitted 12-01-2014

Article Accepted 24-02-2014

**Article previously published in EJEM 2014, vol 1, No. 2 


\section{INTRODUCTION}

Economists have viewed shopping as an activity that allows consumers to maximize their utility function (Michelle, Corrine and Jane, 1995). But customers tend to exhibit 'economic' as well as 'recreational' shopping behavior (Bellenger and Korgaonkar, 1980). For some it is an act of killing boredom, for others it leads to selfgratification and to another category of shoppers it gives a sense of emotional fulfillment (Tauber, 1972). Involvement has also been described as leisure behavior (Bloch and Bruce, 1984). The service industry and in particular the retail sector, has faced tough competition in the recent economic crisis, therefore it is essential for retailers to use the strategies which focus on satisfying the current customers. New retail formats are growing at a rapid pace in India. There remains a need among Indian businesses to understand the changing behavior of customers towards shopping in organized retail outlets. The paradigm shift in consumers socio-economic, demographic and geographical proportions are driving what was once a traditional small-scale retail outlets into an organized retail formats aimed at catering to the evolving needs and tastes of discerning consumers. But the ever changing consumer's psychographic variables like values, activities, interests, opinions, motives and lifestyles have contributed immensely to the growth of store format typologies such as convenience stores, discount stores, super markets and hypermarkets. People's motives for shopping are a function of numerous variables, many of which are unrelated to the actual buying of products. Shopping experience is a utilitarian effort aimed at obtaining needed goods and services as well as hedonic rewards. Literature in marketing and related behavioral sciences suggests a breadth of consumer motives for shopping. The idea that consumers are motivated by more than simply the utilitarian motive to obtain desired items has been acknowledged at least as far back as the 1960s by Howard and Sheth (1969). Their consumer behavior model, in addition to considering traditional explanatory variables such as needs, brand attitudes, and the impact of shopping behavior on promotions, also examined less explicitly utilitarian consumer motives such as arousal seeking and symbolic communication. Tauber (1972) advanced the idea that shoppers were often motivated by a number of personal and social factors unrelated to the actual need to buy products. He proposed that people shop not just to purchase goods, but to learn about new trends, to make themselves feel better, to gain acceptance with their peers, and simply to divert themselves from life's daily routine. Providing an assortment of product and services is one of the basic features of retailer (Levy and Weitz, 2008). As a key component of the marketing mix, assortment represents a strategic positioning tool for customer acquisition and retention (Grewal et al.,1999; Kahn, 1999; Koelemeijer and Oppewal, 1999; and Stassen et al.,1999).From the consumers prespective,assortment plays a fundamental role in store choice(Kelly and Stephenson,1967;Zimmer and Golden,1988;Kahn,1999; and Briesch et al.,2009). The decision about the quality, price levels, and variety of assortment determines the retailer's market position and image (Kunkel and Berry, 1968; Lindquist,1974-1975;Mazursky and Jacoby,1996;Ailawadi and Keller,2004; and Mantrala et al.,2009).Assortment planning is one of the most challenging task in retailing. Especially the dynamics in consumer perceptions and preferences (e.g., desire of variety, and flexibility, preference instability),retailer constraints(e.g., physical space, budget), and changing environmental factors(e.g., competition-related assortment trends, economic conditions) contribute to the huge difficulty of assortment planning(Mantrala et al.,2009). Regardless of any strategic and operational challenges, consumers expect retailers to offer the right mix of products, at the right price, with the right promotions, at the right time and at the right place.

According to Asubonteng et al. (1996), due to intense completion and hostility of environmental factors, service quality has become a cornerstone marketing strategy for companies. This highlights how important it is for the organizations to improve service quality for their survival and growth since it could help them tackle the challenges they face in the competitive markets. This means service based companies are compelled to provide excellent services to their customers in order to have a sustainable competitive advantage.

Service organizations have begun focusing on the customer perception of service quality because it helps in developing strategies that lead to customer satisfaction (Saravanan and Rao,2007).According to Gummesson(1994),there has been a shift from the focus on goods without much emphasis on services to a focus on services while paying attention to goods. This stresses the importance of service marketing to most service industries. In our competitive era, an attractive store ambiance is essential in encouraging customers to buy products. A considerable number of studies have been performed based on the proposition of the environment of 
the store on a satisfaction level and purchase behavior of the consumer (Donovan et al., 1994). Thang and Tan (2003) discovered that store preference is heavily affected by store image. In addition, the store dimensions have significant influence in attracting customers to a store. However, stores can only attract customers if the latter's expectation of the former is fulfilled, and if the customer does not feel a discrepancy between their expectation and what is presented.

The study focuses on hypermarkets, and supermarkets which carry out retailing activities since they deal with the sale of goods and also offer services to the customers in the event of selling goods.

The paper first focuses on the key drivers influencing the shopping behavior in retail store in the relevant literature. It then gives methodological aspects with an emphasis on questionnaire development, sample selection, data collection and data analysis. The data was obtained from a random sample of 300 customers who came for shopping in supermarkets and hypermarkets.

\section{Literature Review}

Service providers and scholars have long recognized the importance of customer satisfaction as contributing to market share and return on investment for companies. Several definitions and models of customer satisfaction have been proposed by various scholars. The focus of much of the research is on the 'disconfirmation of expectations' theory which explains that "the customer is satisfied when he or she feels that the product's performance is equal to more than what was expected(confirmation).But if the perceived performance falls short of his/her expectations(disconfirmation),then if the customer is dissatisfied"(Oliver,1980). Past studies have shown that shoppers' interaction with the shopping environment influences their patronage decision (Babin and Darden, 1995; Li-Wei and Hui, 2004). While some research on store choice has shown the importance of retailer prices on shopping behavior (Arnold and Tigert 1978; Walters and Rinne 1986; Barnard and Hensher 1992; Bell, Ho, and Tang 1998; Bell and Lattin 1998). Zeithaml (1988) opines that consumers' shopping decisions are not based only on price. Though demographic characteristics such as age, income, education and location of residence affect shopping behavior and store choice (Bellenger et al., 1977; Russell et al., 1999; Prasad and Reddy, 2007), the level of income negatively impacts both consumer attitudes and purchase intention (Ioannis et al., 2010).

Thang and Tan (2003) adopting Donovan and Rossiter's (1992) stimulus-organism-response model identified that merchandising, accessibility, reputation, in-store service and atmosphere influence customer preference for a store. Celik (2007) developed a Consumer Store Choice Scale wherein attributes relating to location, price quality of products, sales personnel attitude and physical attractiveness formed the basis for development of the scale. Huddleston et al.,(2009) while studying customer satisfaction in food retailing found that price, product assortment, service and service influence store satisfaction. Forsythe and Baily (1996) and Paulins and Geistfeld (2003) found that age and marital status affect the store choice and time spent on the shopping activity.Chetthamrongchai and Davies (2000) found that the relationship between time and shopping attitudes plays a role in shopper patronage behavior. Shopping behavior based on time and shopping attitude can identify different store preferences for different shopper groups. Hsu et.al.,(2010) identified that distance travelled is positively related to satisfaction which in turn influences behavior intensions with reference to grocery store image.

In the Indian context, Prasad and Aryasri (2011) found that demographic factors have a significant influence on grocery store format choice. Sanjeev Varshney 2006 study found that small town Indian shoppers outshop for pleasure and to seek variety.Mulky and Nargundkar (2003) identified that convenience and merchandise assortment were the most important factors influencing grocery store choice behavior. Sinha and Banerjee (2004) found that store convenience and customer service positively influence consumer store choice. Roy's (2005) study on factors governing consumers choice of supermarkets identified that add-on benefits, general services, convenience and variety, influenced store choice. 
Steenkamp (2001) has observed that by default, research in marketing has mainly focused on developed economies. It is important to note that in the area of retailing there are a dearth of studies in the Indian context, that analyze the parameters shoppers consider important when they decide which store format they want to shop in which parameters they derive maximum utility from(Sinha et.al.,2005). Though choice of a store has been studied from several dimensions including the cost and effort as well as the non-monetary terms, studies relating to the role and impact of store attributes as well as other associated intangibles is limited. Perceived value has become a new strategic imperative for the retailers (Gale, 1994; Sweeney et al 1997; Sweeney and Soutar, 2001; and Levenburg, 2005). Cognitive definitions of perceived value, wherby the concept is posited as a trade-off between benefits and sacrifices, have traditionally been prevalent among marketers (e.g.zeithml, 1988; Dodds, 1991; Chang and Wildt, 1994; Lapierre et al., and Cronin et al.,2000). Perceived service quality has been found to have a positive impact on perceived service value (Bolton and Drew,1991).Holbrook (1994 and 1999) has developed a useful 'typology of value' that captures diverse aspects of consumption experience: (1) economic value(including quality and price); (2)social value;(3) hedonic value; and (4) altruistic value.

According to Holbrook (199), the dimension of 'of 'excellence' involves a reactive appreciation of the potential ability of the object or experience to accomplish a goal or to perform a function. The notion of 'excellence' thus has a utilitarian emphasis with similar connotations to the concept of 'quality' (Holbrook, 1999). Lapierre et al. (1999) contended that quality is an important element of value, and that improving quality is the best way to give the customer better value;moreover,the variety of dimensions that comprise quality makes it possible to differentiate products or services in many ways to enhance their value to customers.

Demographics influence consumer behavior by directly influencing consumer attributes, for example values and decision-making styles (Hyllegard, Eckman, Descals \& Borja, 2005). Furthermore, education influences people's occupations and their occupations greatly determine their income. Bellenger, Robertson and Greenberg (1977) found that the consumers' level of education also influences shopping centre patronage factors as it relates to store image. Consumers' occupation and education influence preferences in products, media and activities, while income provides the necessary means for consumption behavior (Choi\& Park, 2006; Hawkins et al., 2007;Vakratsas,1998). Paulins and Geistfeld (2003)focused on identifying attributes that affect store image preference. They found that consumers are more critical of store image attributes when they have a higher education, but that consumers from different income levels tend to perceive store image similarly. The influence of age on store image perception is frequently investigated. Lumpkin (1985) and Visser and Du Preez (1996) studied the needs of elderly or mature consumers and their findings concluded that age groups within the elderly market differed regarding their preference for store image attributes. Demographic variables in isolation cannot provide a complete picture of the consumer. Studied in isolation, demographics hamper the segmentation process, while demographical characteristics such as age, income and employment status can be misleading. A person's biological age is of less consequence than his/her psychological age, according to Joyce and Lambert (1996).Furthermore, even though income can be tied to spending behavior, it reveals very little about consumer's personal interest, health or discretionary time (Oates et al.,1996). Consumers' lifestyle is therefore a necessary variable when attempting to understand consumer behavior.

Bearden (1977) mentioned the influence of store image as 'consumers choose stores they feel close to their self image,' and he tried to find out store attributes that affect store choice and loyalty for downtown and suburban shopping centers. Hansen and Deutscher (1978) showed that the store image and its attributes make an important role in their choice of retail stores in his study on image attributes. In their model of the process of store choice, Engel, Blackwell, and Miniard (1990) claimed that purchasers' distinguished acceptable stores from unacceptable stores in the process of comparing their evaluation standards with perceived image attributes, and that 'store image is a variable that consumers depend on in their choice of stores.' James, Durand and Dreves (1976) found that image attributes influence consumers' perception and attitudes and they are directly related to sales profits. Schiffman, Dash and Dillion (1977) focused on description of image existing in the competing types of retailers and explained that store image attributes made an important role in the choice of the store type.

According to Collins-Dodd and Lindley (2002), as well as Thang \&Tan (2002), merchandise is considered the most important factor contributing to consumer store preference. This view is supported by 
Birtwistle and Shearer (2000),Collins-Dodd and Lindley (2003), Sullivan et al. (2002) and North et al. (2003), who found that merchandise has a significant influence on brand perception and store choice across consumer segments. Consumers tend to seek stores with a greater assortment of merchandise to satisfy their needs (Sullivan et al., 2002). A single visit to a store where a consumer may meet with unsatisfactory style could disconfirm a consumer's perception and instantly influence the perception of store image (Newman \& Patel, 2004). Erdem et al. (1999) state that consumers who attach greater value to personal gratification would be more inclined to shop at a store with a wide selection of merchandise, whereas Huddleston et al. (1990) found a relationship between the lifestyle characteristics of mature female consumers and merchandise. Hu and Jasper (2006) concluded that a store with more social cues created an even higher favorable preference toward merchandise.

Promotions are a precondition of brand recognition and enhancement, which influence sales (Ratnatunga \& Ewing, 2005).One of the major changes in marketing includes new technology in which advertising is consumer focused to nurture customer satisfaction and loyalty (Kliatchko, 2005). Although promotion is viewed as a positive stimulus by management, a study of patronage motives and product purchase patterns found that special events/exhibits and promotions were among the least mentioned motives for product purchase, and were therefore indicated as less important that other store image attributes (Yavas, 2001).Paulins and Geistfeld(2003) reported a distinct difference between highly educated and less educated consumers in the response to advertising. The fact that educated consumers are more selective makes them more difficult to entice through advertising. Thang and Tan (2003) found that promotions have a significant influence on consumer preference. Consumers have to be constantly attracted by advertising to stimulate interest and create store awareness. But consumers are exposed to a large amount of information and advertising messages; therefore an integrated and consistent marketing communication strategy is critical for strengthening the message which marketers strive to send. Du Frene, Engelland, Lehman and Pearson (2005) found that consumer-centric advertising through interactive e-mailing changed consumers 'attitudes towards the brand, which, in turn, affected intention to purchase.

Chowdhary (1999) notes that convenience is a specifically desirable characteristic for older consumers. In a study by Kim and Jin (2001) convenience was cited as a reason for consumers preferring multinational discount stores over national stores. Store hours comprise another aspect of convenience. Hyllegard et al. (2005) found that store hours are less important to older consumers, because older consumers have more time to shop. Retail stores focusing on younger markets should therefore incorporate a focus around convenience and extended shopping hours. A vital part of convenience is site selection/ location planning, because it influences parking, location and transportation. This is a significant decision because it cannot be altered once made. Location, transportation and traveling time influence the consumer market patronizing the store and, inevitably, sales (Wood \& Browne, 2007). Thang and Tan (2003), for instance, note that retailers are chosen on the basis of accessibility, ease of transportation and time duration of traveling. The importance of traveling distance in influencing intention to remain loyal to a store was noted by Miranda et al. (2005). Newman and Patel (2004) reported that, by focusing on features which influence the ease of shopping, retailers are able to differentiate themselves from the competition.

Facilities refer to the provisions made to ease the shopping process and the infrastructure that enhances the consumer's comfort while shopping (Nevin \& Houston, 1980).According to Thang and Tan (2003), consumers tend to view a store with good facilities in a favorable light. Consumers' shopping orientations determine their preference for facilities (Moye \& Kincade, 2002), therefore facilities contribute to differentiate the retailer from its competition. Features which could differentiate a store by easing the shopping process are the availability of changing rooms, fast checkout facilities and layout (Newman \& Patel, 2004). These authors postulated that customers' perceptions and behavior could be altered through any small change made in store image, specifically store entrances, checkouts and queuing. However, if inappropriate, these features could also create an unwillingness to remain in a store.

Sales personnel play an important role in creating the social cues in a store that are found to improve evaluations of store image (Hu \& Jasper, 2006). The interaction with customers through sales personnel is central to consumer-focused communication (Knee, 2002).Lee et al. (2005), however, did find a 
significant relationship between sales personnel and store loyalty or store satisfaction. Baker et al. (2002) investigated the influence of store environmental cues on customers' perceived merchandise value and patronage intention. They concluded that sales personnel influenced the perceptions of interpersonal service quality, which, in turn, influenced patronage intention, thus underscoring the importance of sales personnel in building store image. The sales personnel's product knowledge is a key store image attribute in male shopping behavior, according to Lee et al. (2005). The personal appearance of sales personnel influences the customers' perception of a store.

Store atmosphere plays a vital role in the consumer's experience. Atmospherics involve a conscious designing of space to affect customers' sensory experience. It mostly has to do with the 'spatial aesthetic' features of the store and serves as a 'silent language' in communication to consumers (Kotler, 1973-1974, p. 48 \& 50). These sensory experiences affect a person's emotional state and therefore the way in which product information will be evaluated. A positive store experience enhances satisfaction and will lead to increased shopping frequency, and therefore lead to increased sales (Koo, 2003). Store atmosphere, specifically in reference to design and ambient factors, is a significant variable as it influences consumer preference, interpersonal service quality, merchandise quality and monetary price perception, as well as shopping experience cost (Baker et al., 2002; Thang \& Tan, 2003). Furthermore, Newman and Patel (2004) reported that store atmosphere is one of the crucial factors and determinants of store choice. Smell (as part of store interior) is a very strong emotional trigger. The sense of pleasant arousal derived from fragrance increases exploratory tendencies behavior (Orth \& Bourrain, 2005). The emotional experience is as important as the shopping experience, because consumers have affective expectations too (Wirtz, Mattila \& Tan, 2007). According to Sway (2007), scent marketing can make a consumer feel comfortable and put consumers in a good mood that could positively influence purchasing decisions. Smell is a strong emotional trigger.

Store image influences the way in which consumers evaluate and choose a store (Kleinhans, 2003). Patronage behavior is associated with acts a consumer performs for the purpose of making a purchase from a store. The identity of a store, presented in the store image, communicates useful information to consumers that they utilize during pre-purchase decision-making (North et al., 2003).Store image cues therefore influence consumers' decision-making processes, which result in store choice (Baker et al., 2002). Store image and store positioning also greatly predict store choice and, ultimately, retail success (Baker et al., 2002). Knowledge about the influence of store image perception on patronage behavior may empower retailers to design their stores according to the desired store image that could lead to consequent store choice (Kleinhans, 2003).Birtwistle and Shearer (2001) propose five reasons why consumers choose a particular store, namely stock held, price ranges, quality of products, fashionability of goods and style of clothing. Four of these fall directly under the dimension of merchandise, which contributes to the forming of a store image (Lindquist, 1974-1975)? Therefore it indicates that store image attributes influence patronage behavior. Satisfied consumers, however, do not necessarily remain satisfied customers, let alone loyal. Customer satisfaction increases repeat purchase behavior and the purchase of other products at the same store (Chang \& Tu, 2005). According to Chen-Yu and Hong (2002), consumers spend their funds in such a way as to maximize satisfaction, which is also the desired outcome of a marketing strategy. Satisfaction not only reinforces the resolution or intent to repurchase, but also store loyalty (Patterson \& Spreng, 1997; Bloemer, Kasper, \& Lemmink, 1990; Kincade, Redwine \& Hancock, 1992).Customer satisfaction is a response to expectation, product performance after purchase, product experience, or the shopping experience. The response is a reaction from the evaluation of standards; between pre-purchase expectations, wants or ideals and the actually shopping- and/ or product experience (Bloemer \& De Ruyter, 1998; Grace,2005; Howard \& Sheth, 1969). Therefore customer satisfaction depends on whether the expectations entertained prior to a shopping experience are met. The greater the satisfaction of the customer during purchasing, the greater the intention to repeat purchase (Chen-Yu \& Hong, 2002). Baker et al.(2002) affirmed that consumers evaluate store image dimensions as reliable information cues about product attributes, price, quality, value and overall shopping experience. Bitner (1990) reported that consumers concentrate on design and ambient environment cues when evaluating a store. According to Jacoby and Mazursky (1984), consumers depend heavily on pictures of store interiors for information during the shopping experience. Customer satisfaction is therefore reached through a positive evaluation of the desired store image. 
It can therefore be deduced that needs satisfaction and shopping satisfaction lead to store choice, which underscores why stores strive toward the needs and goal satisfaction of consumers (Baker et al., 2002). This research outlines the features which can help retailers focus their strategies on appropriate drivers which can influence the shopping behavior of the customers, according to the retailers' own features, and thus attain sustainable competitive advantage through their differentiation.

Marketing literature identifies several store attributes that can differentiate retailers and offer positive value to consumers (e.g.,Hackl et al.,2000;Gomez et al.,et al., 2004., and spiller et al.,2006) including price,sales,sales promotions, quality,commercialized brands (including the store's own brand),proximity,assortment,customer attention, additional services, store atmospherics and opening times,. The findings of a research by Martinez et al. (2010) reveal that among consumers who buy from hypermarkets, perceptions of the quality image, as well as perception of services and convenience, have a positive and significant influence on the maximum level of customer satisfaction. This paper has been taken as a basis for this study and the scale constructed for the study was partially adapted from this paper. This research outlines the features which can help retailers focus their strategies on appropriate consumer's targets, according to the retailer's own features, and thus attain a sustainable competitive advantage through their differentiation.

\section{Objectives of the Study}

The present study focuses on the customer's shopping behavior in retail stores in the Indian context with the following objectives.

- To determine the key drivers influencing Shopping behavior in retail stores; and

- To analyze the relationship between the factors brought out from the study and the different types of customers.

\section{Hypothesis for the Study}

The following hypothesis have been formulated for the study

$\mathrm{H}_{0}$ : The variables are uncorrelated with the population

$\mathrm{H}_{1}$ : The variables are correlated with population

$\mathrm{H}_{2}$ : There is no significant relationship between factors influencing shopping behavior of customer in retail store and different types of buyers.

- There is no significant relationship between shopping experience of customer in retail store and different types of buyers.

- There is no significant relationship between store image of the retail store and different types of buyers.

- There is no significant relationship between perception of value for money that a retail store offers to the customer and different types of buyers.

$\mathrm{H}_{3}$ : There is a significant relationship between factors influencing shopping behavior of customer in retail store and different types of buyers.

- There is a significant relationship between shopping experience of customer in retail store and different types of buyers.

- There is a significant relationship between store image of the retail store and different types of buyers.

- There is a significant relationship between perception of value for money that a retail store offers to the customer and different types of buyers.

\section{Research Methodology}

The Data was collected through questionnaire (refer Appendix) were distributed to customers in different supermarkets and hypermarkets of Lucknow city in the month of May June 2014. 
The sampling technique was probabilistic. Questionnaire was randomly distributed to customers over 18 years of age. The number of valid response was 300 .

\section{Variables Measurement}

Questionnaire measured shopping experience, and value for money perceptions of the customers. Customers rated the store on a 5-point Likert scale. (1=Strongly Disagee to 5=Strongly Agree) for 12 questions related to shopping experience, store image and value for money perceptions of the customers.

\section{Data Analysis}

Table 2 shows the demographics of the respondents for the survey.

Table 1: Demographics of the respondents for the Survey

\begin{tabular}{|c|c|c|c|}
\hline \multirow[t]{3}{*}{ Gender } & Categories & Count & Percentage \\
\hline & Male & 155 & 51.7 \\
\hline & Female & 145 & 48.3 \\
\hline \multirow[t]{4}{*}{ Age } & $<30$ & 105 & 35 \\
\hline & $31-40$ & 114 & 38 \\
\hline & $41-50$ & 54 & 18 \\
\hline & Above 50 & 27 & 9 \\
\hline \multirow[t]{2}{*}{ Marital Status } & Single & 163 & 54.3 \\
\hline & Married & 137 & 45.7 \\
\hline \multirow[t]{3}{*}{ Education Level } & Graduate & 131 & 43.7 \\
\hline & Post Graduate & 115 & 38.3 \\
\hline & Others & 54 & 18 \\
\hline \multirow[t]{5}{*}{ Monthly Income } & $<15,000$ & 19 & 6.3 \\
\hline & $15,0001-20,0000$ & 21 & 7 \\
\hline & $20,0001-30,000$ & 83 & 27.7 \\
\hline & $30,0001-40,000$ & 88 & 29.3 \\
\hline & $>40,000$ & 89 & 29.7 \\
\hline \multirow[t]{4}{*}{ Occupation } & Student & 69 & 23 \\
\hline & Working Professional & 116 & 38.7 \\
\hline & Unemployed & 21 & 7 \\
\hline & Self Employed & 94 & 31.3 \\
\hline
\end{tabular}

\section{Testing of Hypothesis One}

In order to identify the underlying dimensions in the perceptions of key drivers influencing shopping behavior of customers in retail stores, an exploratory factor analysis of principal components was employed. The respondents were asked to rate 12 shopping variables using 5-point Likert scale, which ranged from 'strongly disagree' to 'strongly agree'. The inter-item consistency reliability of these 12 variables was tested before factor analysis was carried out. The result of Cronbach’s Alpha test was 0.964, which is considered to be good. The 
closer the value of Alpha goes to 1.0; the better is the reliability test (Cronbach's, 1951). In order to test whether it was appropriate to apply the exploratory factor analysis technique to this dataset, we used Kaiser-Meyer-Olkin test as a measure of sample adequacy, the results are shown in Table 2, is equal to 0.891 which is greater than the accepted value of 0.5, similarly Bartlett's test of sphericity has a high Chi-square value of 9139.59 and the significance is 0.000 , which is less than 0.05 , hence the null hypothesis is rejected and $\mathrm{H}_{1}$ is accepted.

Table 2: KMO and Bartlett's Test

\begin{tabular}{|lll|}
\hline $\begin{array}{l}\text { Kaiser-Meyer-Olkin Measure of } \\
\text { Sampling Adequacy }\end{array}$ & $\mathbf{0 . 8 9 1}$ \\
\hline Bartlett's Test of Sphericity & Approx.Chi-Square & 9139.159 \\
& df & 66 \\
& Sig. & 0.000 \\
\hline
\end{tabular}

Table 3 shows the factor analysis of the 12 variables which would be considered as key drivers influencing the shopping behavior of the customer's in retail stores.

Table 3: Factor Analysis

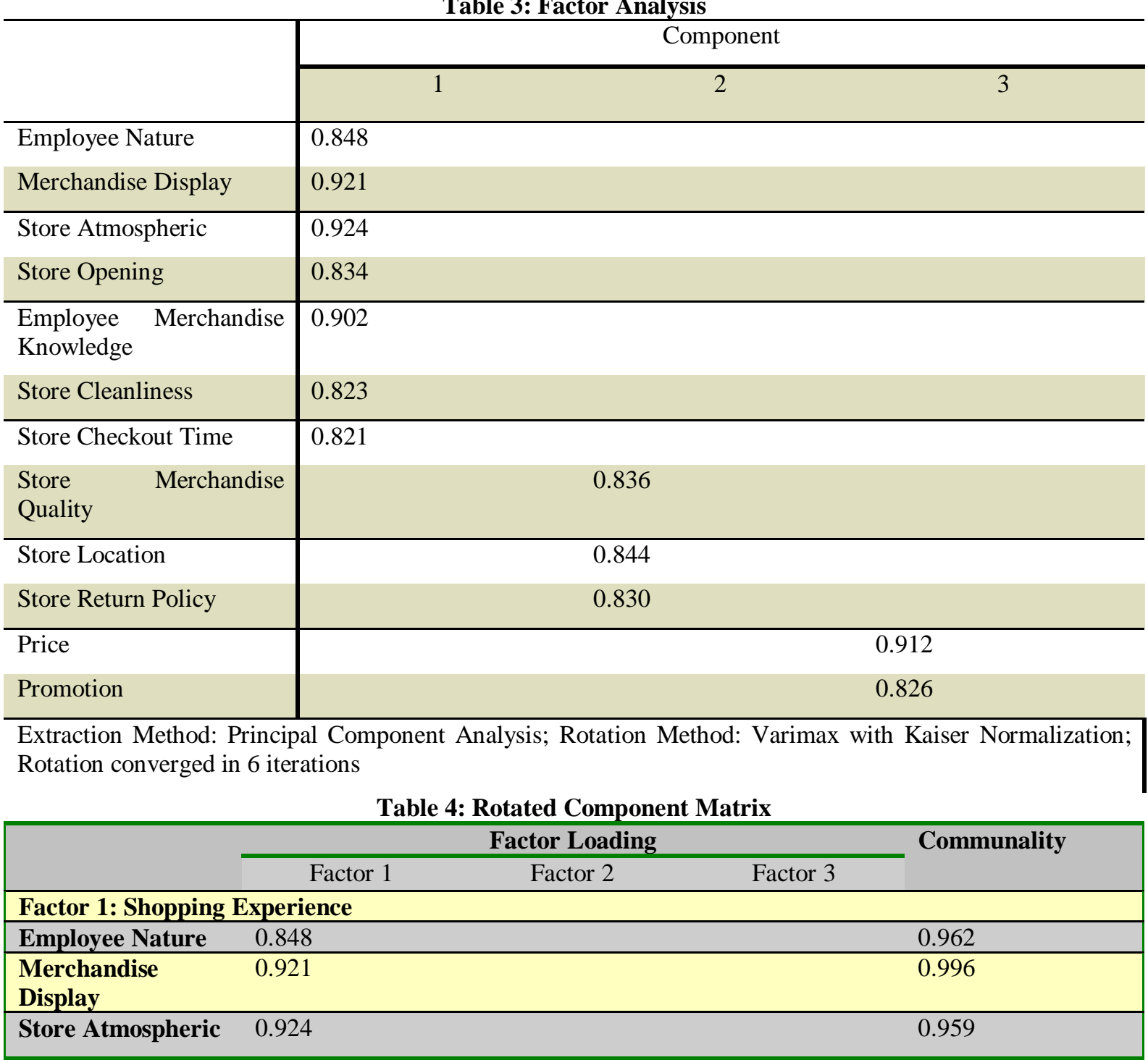




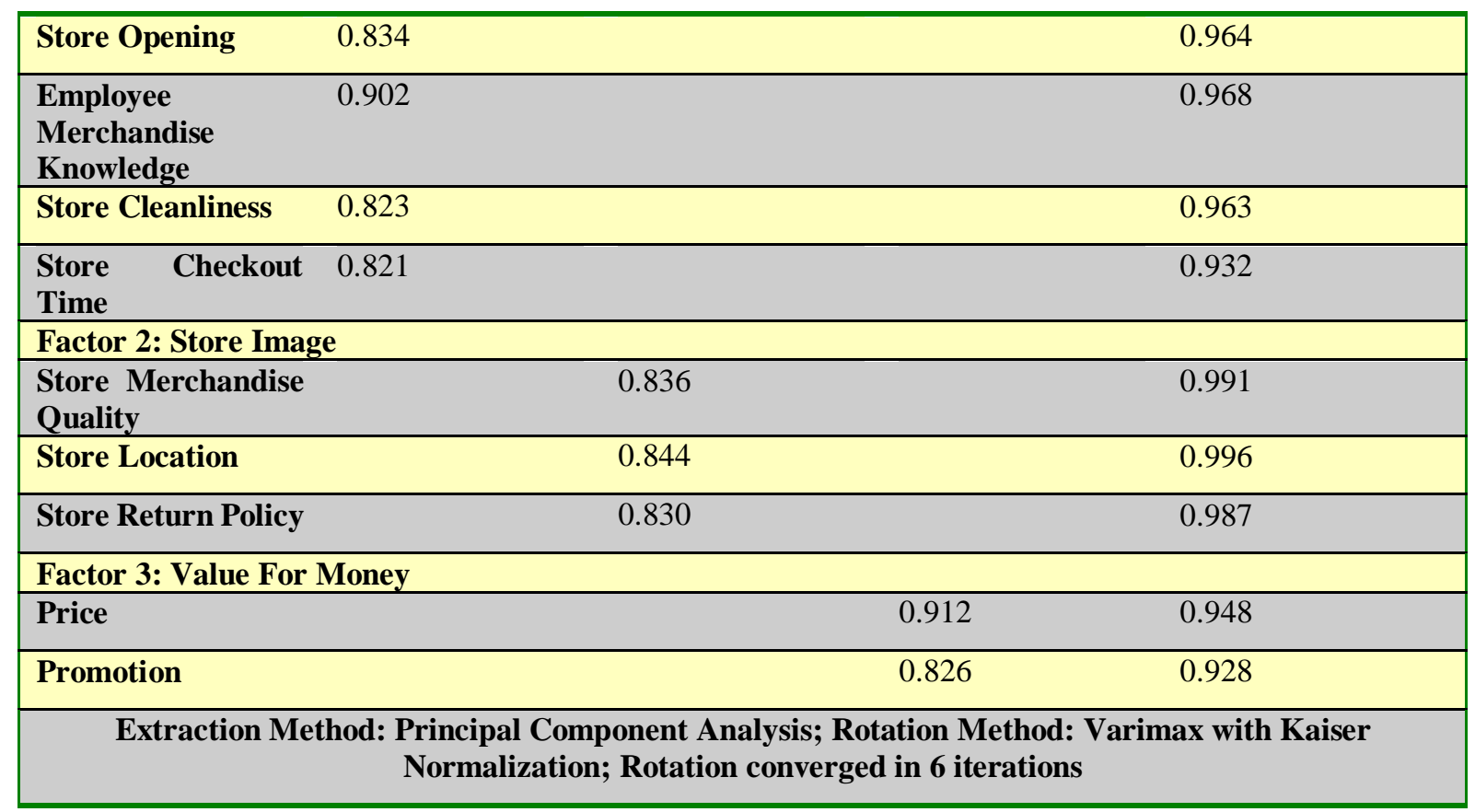

These three factors account for $96.36 \%$ of the variation in the 12 variables (Table 5).

Table 5: Total Variance

\begin{tabular}{|c|c|c|c|c|c|c|c|c|c|}
\hline \multirow[b]{2}{*}{ Component } & \multicolumn{3}{|c|}{ INITIAL EIGEN VALUES } & \multicolumn{3}{|c|}{$\begin{array}{lcc}\text { EXTRACTION } & \text { SUM } & \text { OF } \\
\text { SQUARED LOADINGS } & \end{array}$} & \multicolumn{3}{|c|}{$\begin{array}{lcc}\text { ROTATION } & \text { SUMS } & \text { OF } \\
\text { SQUARED LOADINGS } & \end{array}$} \\
\hline & Total & $\begin{array}{l}\% \text { of } \\
\text { Variance }\end{array}$ & $\begin{array}{l}\text { Cumulative } \\
\%\end{array}$ & Total & $\begin{array}{l}\text { \% of } \\
\text { Variance }\end{array}$ & $\begin{array}{l}\text { Cumulative } \\
\%\end{array}$ & Total & $\begin{array}{l}\text { \% of } \\
\text { Variance }\end{array}$ & $\begin{array}{l}\text { Cumulative } \\
\%\end{array}$ \\
\hline 1 & 9.479 & 78.989 & 78.989 & 9.479 & 78.989 & 78.989 & 5.571 & 46.422 & 46.422 \\
\hline 2 & 1.1440 & 12.000 & 90.989 & 1.1440 & 12.000 & 90.989 & 3.586 & 29.880 & 76.302 \\
\hline 3 & 1.01 & 5.374 & 98.362 & 1.01 & 5.374 & 98.362 & 2.407 & 20.060 & 96.362 \\
\hline & & & $n t$ & & & & & & \\
\hline
\end{tabular}

Further the internal consistency was found to be good for three attributes, the results of Cronbach's Alpha for the three attributes were $0.990, .0 .995$ and 0.903 respectively, which is well above the permissible value of 0.5.The closer the reliability coefficient gets to the value of 1.0,the better is the reliability of the measure(Cronbach 1951). This scale can be considered good.

Table 6: Reliability Statistics

\begin{tabular}{lll}
\hline & Cronbach's Alpha & No. of Items \\
\hline Factor 1:Shopping Experience & 0.995 & 7 \\
Factor 2:Store Image & 0.990 & 3 \\
Factor 3:Value For Money & 0.903 & 2 \\
\hline
\end{tabular}




\subsection{Scree Plot}

A scree plot is a plot of eigenvalues against the number of factors in order of extraction. As shown in Figure 1,it indicates that there are three factors which have eigenvalues greater than one based on 12 variables.

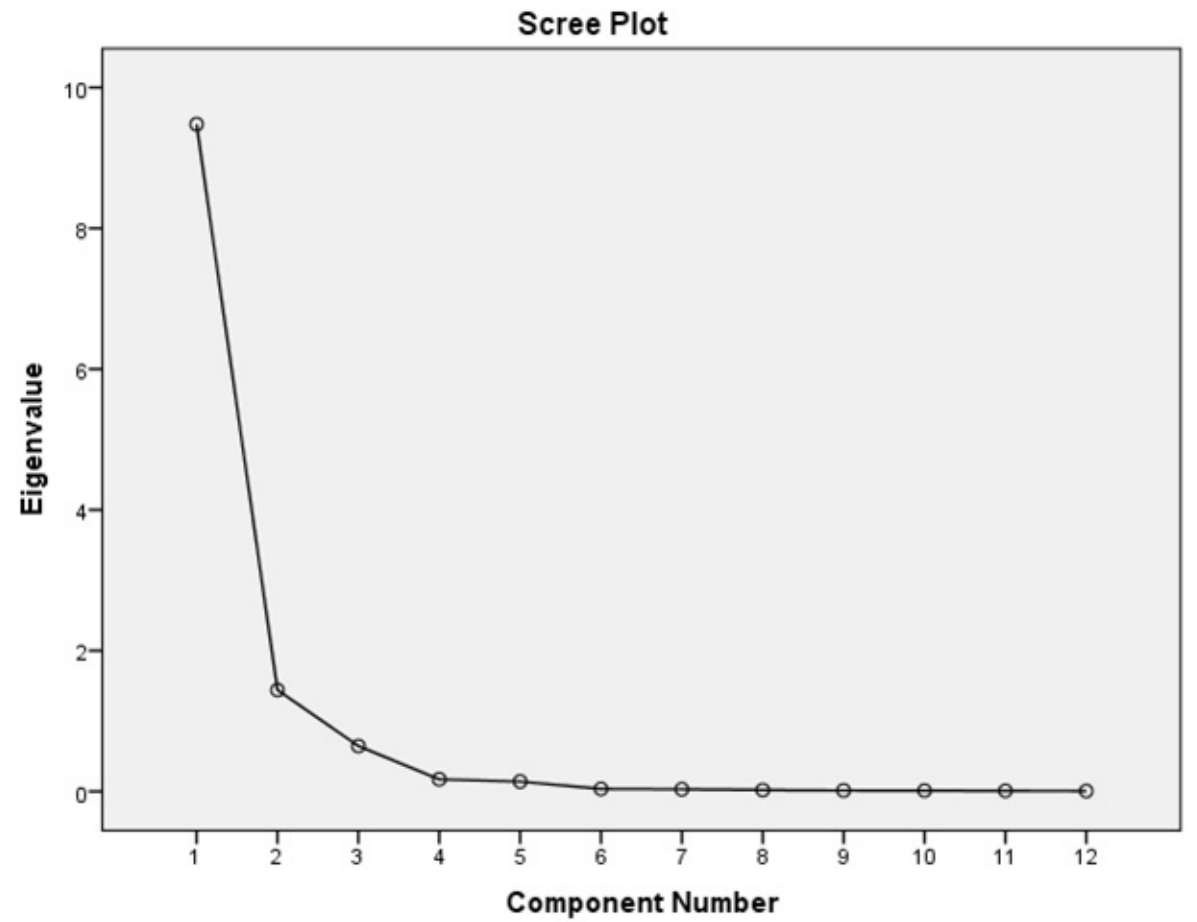

Figure 1: Scree Plot

\section{Testing Hypothesis 2}

$\mathrm{H}_{2}$ : There is no significant relationship between factors influencing shopping behavior of customer in retail store and different types of buyers.

- There is no significant relationship between shopping experience of customer in retail store and different types of buyers.

- $\quad$ There is no significant relationship between store image of the retail store and different types of buyers.

- There is no significant relationship between perception of value for money that a retail store offers to the customers and different types of buyers.

$\mathrm{H}_{3}$ : There is a significant relationship between factors influencing shopping behavior of customer in retail store and different types of buyers.

- $\quad$ There is a significant relationship between shopping experience of customer in retail store and different types of buyers.

- There is a significant relationship between store image of the retail store and different types of buyers.

- There is a significant relationship between perception of value for money that a retail store offers to the customer and different types of buyers.

\section{Models and Analysis of Results}

In order to test the hypothesis a parametric linear regression and one way ANOVA test were conducted .Table 7, 8 and 9 shows the values of the coefficient of determination of $\mathrm{R}^{2}$ that quantifies the proportion of variation explained by the model. Regarding the total sample of customers it shows that $74.9 \%$ of the variation of the shopping experience of the customers shopping in retail store is explained by this model (Table 7). 
Table 7: Model Summary Shopping Experience

\begin{tabular}{lllll}
\hline Model & R & R Square & $\begin{array}{l}\text { Adjusted } \mathbf{R} \\
\text { Square }\end{array}$ & $\begin{array}{l}\text { Std.Error of the } \\
\text { Estimate }\end{array}$ \\
\hline $\mathbf{1}$ & 0.865 & 0.749 & 0.744 & 0.50616710 \\
\hline
\end{tabular}

Table 8: Model Summary Store Image

\begin{tabular}{lllll}
\hline Model & R & R Square & $\begin{array}{l}\text { Adjusted } \mathbf{R} \\
\text { Square }\end{array}$ & $\begin{array}{l}\text { Std.Error of the } \\
\text { Estimate }\end{array}$ \\
\hline $\mathbf{1}$ & 0.564 & 0.318 & 0.304 & 0.83451877 \\
\hline
\end{tabular}

Table 9: Model Summary Value for Money

\begin{tabular}{lllll}
\hline Model & R & R Square & $\begin{array}{l}\text { Adjusted } \mathbf{R} \\
\text { Square }\end{array}$ & $\begin{array}{l}\text { Std.Error of the } \\
\text { Estimate }\end{array}$ \\
\hline $\mathbf{1}$ & 0.367 & 0.135 & 0.117 & 0.93958115 \\
\hline
\end{tabular}

ANOVA test was also conducted to test the hypothesis and the results are shown in table 10

Table 10: ANOVA

\begin{tabular}{|c|c|c|c|c|c|c|}
\hline & & $\begin{array}{l}\text { Sum of } \\
\text { Squares }\end{array}$ & df & $\begin{array}{l}\text { Mean } \\
\text { Square }\end{array}$ & $\mathbf{F}$ & Sig \\
\hline \multirow[t]{3}{*}{$\begin{array}{l}\text { Shopping } \\
\text { Experience }\end{array}$} & $\begin{array}{l}\text { Between } \\
\text { Groups }\end{array}$ & 192.012 & 2 & 96.006 & 266.514 & 0.000 \\
\hline & $\begin{array}{l}\text { Within } \\
\text { Groups }\end{array}$ & 106.988 & 297 & 0.360 & & \\
\hline & Total & 299.000 & 299 & & & \\
\hline \multirow[t]{3}{*}{ Store Image } & $\begin{array}{l}\text { Between } \\
\text { Groups }\end{array}$ & 55.668 & 2 & 27.834 & 33.973 & 0.000 \\
\hline & $\begin{array}{l}\text { Within } \\
\text { Groups }\end{array}$ & 243.332 & 297 & 0.819 & & \\
\hline & Total & 299.00 & 299 & & & \\
\hline \multirow[t]{3}{*}{$\begin{array}{c}\text { Value For } \\
\text { Money }\end{array}$} & $\begin{array}{l}\text { Between } \\
\text { Groups }\end{array}$ & 20.685 & 2 & 10.343 & 11.037 & 0.000 \\
\hline & $\begin{array}{l}\text { Within } \\
\text { Groups }\end{array}$ & 278.315 & 297 & 0.937 & & \\
\hline & Total & 299.00 & 299 & & & \\
\hline
\end{tabular}

\subsection{Interpretation}

All the three factors have significance value of 0.000 respectively which is less than 0.05 and therefore the $\mathrm{H}_{2}$ hypothesis is rejected and $\mathrm{H}_{3}$ is accepted as which states that their exist a relationship between shopping experience, store image, value for money with different types of buyers i.e. buyers of different age groups, gender, marital status, income, education level and occupation. 
Analysis of descriptive statistics of shopping experience (Table 11) indicates that the people who are below 30, single and whose monthly income is more than Rs. 40,000 do enjoy shopping more as an experience, similarly males enjoy shopping more as an experience as compared to females. The study also indicates that people who are above 50 years don’t enjoy shopping as an experience.

Table 11: Descriptive Statistics for Shopping Experience

\begin{tabular}{|c|c|c|c|c|c|c|c|c|}
\hline & \multirow[t]{2}{*}{$\mathbf{N}$} & \multirow[t]{2}{*}{ Mean } & \multirow[t]{2}{*}{ SD } & \multirow[t]{2}{*}{$\begin{array}{l}\text { Std } \\
\text { Error }\end{array}$} & \multicolumn{2}{|c|}{$\begin{array}{l}5 \% \text { Confidence } \\
\text { Level Mean }\end{array}$} & \multirow[t]{2}{*}{ Min } & \multirow[t]{2}{*}{ Max } \\
\hline & & & & & $\begin{array}{l}\text { Lower } \\
\text { Bound }\end{array}$ & $\begin{array}{l}\text { Upper } \\
\text { Bound }\end{array}$ & & \\
\hline \multicolumn{9}{|c|}{ Shopping Experience Descriptive Statistics } \\
\hline \multicolumn{9}{|l|}{ Age } \\
\hline Less than 30 & 105 & 0.80 & 0.33 & 0.32 & 0.73 & 0.86 & 0.51 & 1.2 \\
\hline 31-40 & 114 & 0.27 & 0.53 & 0.49 & 0.17 & 0.37 & -1.5 & 1.2 \\
\hline 41-50 & 54 & -.1 .63 & 0.19 & 0.02 & -1.69 & -1.58 & -2.1 & -1.5 \\
\hline Above 50 & 27 & -1.0 & 0.43 & 0.08 & -1.17 & -0.83 & -1.9 & -0.4 \\
\hline \multicolumn{9}{|c|}{ Marital Status } \\
\hline Single & 163 & 0.70 & 0.38 & 0.02 & 0.64 & 0.76 & 0.29 & 1.2 \\
\hline Married & 137 & -0.84 & 0.84 & 0.07 & -0.98 & -0.69 & -2.1 & 0.29 \\
\hline \multicolumn{9}{|c|}{ Education Level } \\
\hline Graduate & 131 & 0.80 & 0.35 & 0.03 & 0.74 & 0.86 & 0.29 & 1.20 \\
\hline $\begin{array}{l}\text { Post } \\
\text { Graduate }\end{array}$ & 115 & -0.29 & 0.85 & 0.07 & -0.43 & -1.41 & -1.53 & 0.29 \\
\hline Others & 54 & -1.33 & 0.55 & 0.07 & -1.49 & -1.87 & -2.14 & 0.29 \\
\hline \multicolumn{9}{|l|}{ Gender } \\
\hline Male & 155 & 0.72 & 0.37 & 0.03 & 0.06 & 0.07 & 0.29 & 1.20 \\
\hline Female & 145 & -0.77 & 0.86 & 0.07 & -0.91 & -0.63 & -2.1 & 0.29 \\
\hline \multicolumn{9}{|l|}{ Occupation } \\
\hline Student & 69 & 0.58 & 0.19 & 0.02 & 0.54 & 0.63 & 0.51 & 1.20 \\
\hline $\begin{array}{l}\text { Working } \\
\text { Professional }\end{array}$ & 116 & 0.69 & 0.45 & 0.04 & 0.61 & 0.78 & 0.29 & 1.20 \\
\hline Unemployed & 21 & 0.25 & 0.14 & 0.03 & 0.18 & 0.37 & -0.31 & 0.29 \\
\hline $\begin{array}{l}\text { Self } \\
\text { Employed }\end{array}$ & 94 & -1.35 & 0.45 & 0.04 & -1.44 & -1.25 & -0.21 & -0.31 \\
\hline \multicolumn{9}{|l|}{ Income Level } \\
\hline $\begin{array}{l}20,0001- \\
30,000\end{array}$ & 83 & 0.99 & 0.31 & 0.03 & 0.19 & 0.28 & -0.92 & 0.29 \\
\hline $\begin{array}{l}30,0001- \\
40,000\end{array}$ & 88 & 0.23 & 0.21 & 0.02 & 0.19 & 0.28 & -.92 & 0.29 \\
\hline $\begin{array}{l}\text { Above } \\
40,000\end{array}$ & 89 & 1.3 & 0.41 & 0.04 & 1.4 & 1.3 & 2.1 & 0.40 \\
\hline
\end{tabular}

Analysis of descriptive statistics of store image (Table 12) indicates that the people who are of above 50 years and who earn more than Rs.40,000, while shopping keep in mind the store image or rather shop more where they perceive the store image to be better in comparison to the other stores. 
Table 12: Descriptive Statistics for Store Image

\begin{tabular}{|c|c|c|c|c|c|c|c|c|}
\hline & \multirow[t]{2}{*}{$\mathbf{N}$} & \multirow[t]{2}{*}{ Mean } & \multirow[t]{2}{*}{ SD } & \multirow[t]{2}{*}{$\begin{array}{l}\text { Std } \\
\text { Error }\end{array}$} & \multicolumn{2}{|c|}{$\begin{array}{l}5 \% \text { Confidence } \\
\text { Level } \\
\text { Mean }\end{array}$} & \multirow[t]{3}{*}{ Min } & \multirow[t]{2}{*}{ Max } \\
\hline & & & & & $\begin{array}{l}\text { Lower } \\
\text { Bound }\end{array}$ & $\begin{array}{l}\text { Upper } \\
\text { Bound }\end{array}$ & & \\
\hline \multicolumn{8}{|c|}{ Store Image Descriptive Statistics } & \\
\hline \multicolumn{9}{|l|}{ Age } \\
\hline Less than 30 & 105 & 0.53 & 0.98 & 0.09 & 0.34 & 0.72 & -0.67 & 1.36 \\
\hline $31-40$ & 114 & -0.23 & 0.25 & 0.02 & -0.27 & -0.18 & -0.67 & 0.62 \\
\hline 41-50 & 54 & 0.50 & 0.40 & 0.05 & 0.39 & 0.61 & -1.3 & 0.91 \\
\hline Above 50 & 27 & 2.0 & 0.72 & 0.14 & 2.3 & 1.80 & 3.2 & 0.90 \\
\hline \multicolumn{9}{|c|}{ Marital Status } \\
\hline Single & 163 & 0.21 & 0.90 & 0.07 & 0.07 & 0.35 & -0.67 & 1.36 \\
\hline Married & 137 & -0.25 & 1.04 & 0.08 & -0.43 & -0.08 & -3.2 & 0.91 \\
\hline \multicolumn{9}{|c|}{ Education Level } \\
\hline Graduate & 131 & 0.32 & 0.97 & 0.08 & 0.15 & 0.49 & -0.67 & 1.36 \\
\hline $\begin{array}{l}\text { Post } \\
\text { Graduate }\end{array}$ & 115 & 0.03 & 0.38 & 0.03 & -0.03 & 0.10 & -3.2 & 0.91 \\
\hline Others & 54 & -0.87 & 1.39 & 0.18 & -1.25 & -0.49 & -3.2 & 0.91 \\
\hline \multicolumn{9}{|l|}{ Gender } \\
\hline Male & 155 & 0.24 & 0.92 & 0.07 & 0.09 & 0.38 & -0.67 & 1.38 \\
\hline Female & 145 & -0.25 & 1.01 & 0.08 & 0.42 & 0.08 & -3.2 & 0.91 \\
\hline \multicolumn{9}{|l|}{ Occupation } \\
\hline Student & 69 & 1.16 & 0.56 & 0.06 & 1.02 & 1.29 & -0.67 & 1.36 \\
\hline $\begin{array}{l}\text { Working } \\
\text { Professional }\end{array}$ & 116 & -0.43 & 0.21 & 0.01 & -0.47 & -0.39 & -0.67 & -0.24 \\
\hline Unemployed & 21 & -0.21 & 0.06 & 0.01 & -0.25 & -0.18 & -.024 & 0.47 \\
\hline $\begin{array}{l}\text { Self } \\
\text { Employed }\end{array}$ & 94 & -0.27 & 1.26 & 0.13 & -0.53 & -0.10 & -3.2 & 0.91 \\
\hline \multicolumn{9}{|l|}{ Income Level } \\
\hline $\begin{array}{l}20,0001- \\
30,000\end{array}$ & 83 & -0.11 & 0.86 & 0.09 & -0.30 & 0.07 & -0.67 & 1.36 \\
\hline $\begin{array}{l}30,0001- \\
40,000\end{array}$ & 88 & -0.21 & 0.10 & 0.01 & -0.23 & -0.19 & -0.24 & 0.33 \\
\hline $\begin{array}{l}\text { Above } \\
40,000\end{array}$ & 89 & 0.29 & 1.29 & 0.13 & 0.56 & 0.02 & 3.29 & 0.91 \\
\hline
\end{tabular}

Analysis of descriptive statistics of value for money (Table 13) indicates that the people who are in the age group of 41-50, unemployed and whose monthly income is in between 20, 0001-30,000 tend to shop more in stores where they perceive that the stores offer them a better value of their money. The study also indicates that people who earn more than Rs.40,000 don’t consider the value for money factor while shopping.

Table 13: Descriptive Statistics for Value for Money

\begin{tabular}{|c|c|c|c|c|c|c|c|c|}
\hline & $\mathbf{N}$ & Mean & SD & $\begin{array}{l}\text { Std } \\
\text { Error }\end{array}$ & $\begin{array}{l}5 \% \text { Co } \\
\text { Level } \\
\text { Mean }\end{array}$ & ence & Min & Max \\
\hline & & & & & $\begin{array}{l}\text { Lower } \\
\text { Bound }\end{array}$ & $\begin{array}{l}\text { Upper } \\
\text { Bound }\end{array}$ & & \\
\hline Value For M & ney D & ive $S$ & & & & & & \\
\hline Age & & & & & & & & \\
\hline Less than 30 & 105 & -0.10 & 0.35 & 0.34 & -0.17 & -0.03 & -0.4 & 0.33 \\
\hline $31-40$ & 114 & 0.28 & 0.02 & 0.002 & 0.28 & 0.28 & 0.19 & 0.33 \\
\hline $41-50$ & 54 & 0.29 & 0.26 & 0.03 & 0.22 & 0.38 & 0.17 & 1.38 \\
\hline Above 50 & 27 & -1.38 & 2.87 & 0.55 & -2.52 & -0.24 & -5.4 & 1.77 \\
\hline
\end{tabular}




\begin{tabular}{|c|c|c|c|c|c|c|c|c|}
\hline Single & 163 & 0.03 & 0.34 & 0.02 & -0.01 & 0.09 & -0.40 & 0.33 \\
\hline Married & 137 & -0.44 & 1.43 & 0.12 & -0.28 & 0.19 & -5.4 & 1.77 \\
\hline \multicolumn{9}{|c|}{ Education Level } \\
\hline Graduate & 131 & -0.02 & 0.36 & 0.03 & -0.08 & 0.03 & -0.40 & 0.33 \\
\hline $\begin{array}{l}\text { Post } \\
\text { Graduate }\end{array}$ & 115 & 0.25 & 0.03 & 0.003 & 0.24 & 0.26 & 0.19 & 0.28 \\
\hline Others & 54 & -0.49 & 2.22 & 0.30 & -1.09 & 0.11 & -5.4 & 1.77 \\
\hline \multicolumn{9}{|l|}{ Gender } \\
\hline Male & 155 & 0.024 & 0.34 & 0.02 & -0.03 & 0.08 & -0.04 & 0.33 \\
\hline Female & 145 & -0.026 & 0.34 & 0.02 & -0.03 & 0.08 & -0.40 & 0.33 \\
\hline \multicolumn{9}{|l|}{ Occupation } \\
\hline Student & 69 & -0.33 & 0.20 & 0.02 & -0.38 & -0.28 & -0.40 & 0.33 \\
\hline $\begin{array}{l}\text { Working } \\
\text { Professional }\end{array}$ & 116 & 0.30 & 0.02 & 0.002 & 0.301 & 0.309 & 0.28 & 0.33 \\
\hline Unemployed & 21 & 0.28 & 0.005 & 0.001 & 0.281 & 0.286 & 0.26 & 0.28 \\
\hline $\begin{array}{l}\text { Self } \\
\text { Employed }\end{array}$ & 94 & -0.19 & 1.71 & 0.17 & -0.54 & 0.15 & -5.4 & 1.77 \\
\hline \multicolumn{9}{|l|}{$\begin{array}{l}\text { Income } \\
\text { Level }\end{array}$} \\
\hline $\begin{array}{l}\text { 20,0001- } \\
30,000\end{array}$ & 83 & 0.13 & 0.31 & 0.03 & 0.06 & 0.20 & -0.40 & 0.33 \\
\hline $\begin{array}{l}\text { 30,0001- } \\
40,000\end{array}$ & 88 & 0.28 & 0.009 & 0.001 & 0.282 & 0.280 & 0.22 & 0.28 \\
\hline $\begin{array}{l}\text { Above } \\
40,000\end{array}$ & 89 & -0.22 & 1.75 & 0.18 & -0.59 & 0.14 & -5.4 & 1.77 \\
\hline
\end{tabular}

\section{Conclusion}

A great portion of the competitive advantage of retailer directly depends on the amount of information obtained from the customers. The information obtained from the customers enables the retailer to know the key drivers which would influence the shopping behavior of the customers in the retail store. The customers who have different consumption habits with different income levels want something in common, to enjoy their shopping in a decent environment. Customers while going through the purchase cycle, experiences some attitude/behavior changes based on the stimulus in the environment, which leads to formation of certain judgments about the store, These judgments in turn influences how customer behaves.

This research primarily helps to identify the key drivers which influence the shopping behavior of the customers in the retail stores The finding shows that shopping experience, store image and value for money had a significant impact on shopping behavior of the customer in both hypermarkets and supermarkets. Focusing on the drivers which are of greatest importance and have highest share in influencing the shopping behavior of the customers in the retail store, which would enable the retail store to identify their strength and weakness, while also identify the opportunities and the threats of the external environment. It is inferred from the results that better display of merchandise, keeping the store clean, reducing the billing time, and a positive store atmosphere can lead to more satisfying buying experience.

\section{Limitations of the Study}

Due to lack of time and resources the study was limited to the survey of customers in Hypermarkets and Supermarkets of Lucknow district. Although, Lucknow district is a two tier city and capital city of Uttar Pradesh, the findings may not entirely reflect the views of customers of entire country in general and the results may vary in case the survey is conducted in other parts of the country. Hence, research in other cities and other customers 
is required to examine the validity and reliability of the identified store attributes. The researchers found it very difficult to make the respondents answer for lengthy questions as they were in shopping mood and neglect to answer the questions.

\section{Future Research}

A possible direction for future research is to review and conduct a similar study in other districts, or states to discover similarities and differences. Another possible direction for future research is to examine the other factors such as shopping frequency, the ticket size of the purchase and compare different types of retail stores such as discount stores may explain other key drivers which would influence the shopping behavior of customers in retail store.

\section{References}

Abelson, R. P., Kinder, D. R., Peters, M. D., and Fiske, S. T. (1982). Affective and semantic components in political person perception. Journal of Personality and Social Psychology, 42, 619-630.

Alba Joseph W and Hutchinson Wesley J (1987), “Dimensions of Consumer Expertise,” Journal of Consumer Research, 13, (March), $411-454$.

Arnould E.J. and M. Wallendorf (1994), "Market-oriented Ethnography: Interpretation Building and Marketing Strategy Formulation”, Journal of Marketing Research, 31 (4), pp. 484-504.

Anuradha M K, Sinha P K and Krishna R (2003), "Children in a Kirana Store: Building a Case for Retail Communication”, Journal of Brand Management, Vol. 10 (3), February, pp. 219-232.

Arora R (1982), “Involvement: Its Measurement for Retail Store Research”, Journal of the Academy of Marketing Science, Vol. 10, No. 2, pp. 109-124.

Berman Barry and Joel Evans (2003), 'Retail Management: A Strategic Approach’, 9/E, Prentice Hall, Pearson Education, One Lake Street, Upper Saddle River, NJ, USA.

Belk, Russell W. (1975), "Situational Variables and Consumer Behavior," Journal of Consumer Research, 2 (December), 157-164.

Bellenger, Danny N., and Pradeep K. Korgaonkar (1980), "Profiling the Recreational Shopper, "Journal of Retailing, 56 (Fall), 77-92.

Bhatnagar, A. and Ratchford, B. T. (2004). A model of retail format competition for non-durable goods. International Journal of Research in Marketing, 21(1), 39-59.

Bloch, P.H. and M.L. Richins (1983), "A Theoretical model for the Study of Product Importance Perceptions," Journal of Marketing, 47, 3 (Summer), 69-81.

Brucks, Merry (1985), “The Effects of Product Class Knowledge on Information and Search Behavior,” Journal of Consumer Research, 12, (June), 1-16.

Chugani, Harry T. (1998). Biological Basis of emotions: Brain Systems and Brain Development. Pediatrics Vol. 102(5). Supplement November 1998, 1225-1229.

De Bruicker, F.S. (1979), "An Appraisal of Low-Involvement Consumer Information Processing," in Attitude Research Plays for High Stakes, J.C. Maloney and B. Silverman, eds., American Marketing Association, 112130.

Drew, C. J. and Hardman, M. L. (1987). Designing and conducting behavioral research, New York: Pergamon Press. 
Duncan, Calvin P. And Richard W. Olshavsky (1982), "External Search: The Role of Consumer Beliefs," Journal of Marketing Research, 19 (February), 32-43.

Farley, Sally and Stasson, Mark (2003). Relative influences of affect and cognition on behavior: Are feelings more related to blood donation intentions?, Experimental Psychology, Vol.50, 55-62.

Galata, G., Bucklin R.E., Hanssens, D.M. 1999. On the Stability of Store Format Choice. Working paper, Anderson School at UCLA.

Hair, J. F., Anderson, R. E., Tatham, R. L., and Black, W. C. (2003). Multivariate data analysis. New Delhi: Pearson.

Hean Tat Keh (1997), “The Classification of Distribution Channel Output: a Review”, The International Review of Retail, Distribution and Consumer Research, 7 (2). 145-156.

Howard, J. and Sheth, J.N. (1968), Theory of Buyer Behavior, J. Wiley \& Sons, New York.

Johnson Eric. J and Russo Edward J (1984), “Product Familiarity and Learning New Information”, Journal of Consumer Research, 11, June, 542- 550.

Kassarjian Harold H. (1981), "Low Involvement: A Second Look", in Advances in Consumer Research Volume 08, eds. Kent B. Monroe, Ann Abor, Association for Consumer Research, Pages: 31-34.

Kollat David T and Ronald P. Willett (1967), "Customer Impulse Purchasing Behavior," Journal of Marketing Research, 4, pp. 21-31.

Krugman, H.E. (1967), "The Measurement of Advertising Involvement," Public Opinion Quarterly, 30, pp. 583 - 596.

Laurent, G., and Kapferer, J. N. (1985a), "Measuring consumer involvement profiles", Journal of Marketing Research, Vol. 12 pp.41-53.

Lastovicka, J.L., and Gardner, D.M. (1979), "Components of involvement," in Attitude research plays for high stakes, eds., J. Maloney and B. Silverman, Chicago: American Marketing Association, pp.53-73.

Lavine, H., Thomsen, C. J., Zanna, M. P., and Borginda, E. (1998). On the primacy of affect in the determination of attitudes and behavior: The moderating role of affective-cognitive ambivalence. Journal of Experimental Social Psychology, 34, 398-421.

Messinger, Paul R and Narasimhan, Chakravarthi (1997), "A Model of Retail Formats Based on Consumers' Economising on Shopping Time", Marketing Science, Vol. 16, No. 1, pp. 1 -23.

Millar, M. G., and Millar, K. U. (1990). Attitude change as a function of attitude type and argument type. Journal of Personality and Social Psychology, 59, 217-228.

Newman, Joseph W. and Staelin, Richard (1973), “Information Sources of Durable Goods”, Journal of Advertising Research, April, Vol. 13 Issue 2, 19 - 29.

Pierre Martineau (1958), “The Personality of the Retail Store”, Harvard Business Review, Vol. 36,Jan - Feb, pp. $47-55$.

POPAI (1995a), “Consumer Buying Habits Study: Measuring the In Store Decision Making of Supermarket and Mass Merchandise Store Shoppers”, New Jersey, 66, North Van Brunt Street, USA.

POPAI (1995b), “Establishing POP Advertising as a Measured Medium”, Pilot Survey Report, ARF and Prime Consulting Group Inc, Washington DC. 
Rao, Akshay R. and Kent B. Monroe (1988), “The Moderating Effect of Price Prior Knowledge On Cue Utilization in Product Evaluations,” Journal Of Consumer Research, 15, September, 253-264.

Ray, M.L. (1974), "Consumer initial processing: Definitions, issues, and applications," in Buyer/Consumer information processing, eds., G. Hughes and M. Ray, Chapel Hill: University of North Carolina Press, pp. 145156.

Robertson, T.S. (1976), “Low Commitment Consumer Behavior,” Journal of Advertising Research,16 (April), $19-24$.

Sheth J. and M. Venkatesan (1968), Risk-reduction processes in repetitive consumer behavior, Journal of Marketing Research 5 (1968), pp. 307-310.

Sinha Piyush Kumar (2003), “Shopping Orientation in the Evolving Indian Market”, Vikalpa, Vol. 28 (2), AprilJune,pp.13-22.

Slama, M.E. and Tashchian, A. (1985), "Selected socioeconomic and demographic characteristics associated with purchasing involvement", Journal of Marketing, Vol. 49 pp.72-82.

Tauber E (1972), “Why Do People Shop”, Journal of Marketing, 36 (Oct), pp. 56-59.

Tybjee, T.T. (1979), "Refinement of the Involvement Concept: An Advertising Planning Point of View," in Attitude Research Plays for High Stakes, eds., J.C. Maloney and B. Silverman, Chicago: American Marketing Association, 94-111.

Westbrook R A and Black W C (1985), “A Motivation Based Shopper Typology, “Journal of Retailing, Volume 61, No1, Spring pp. 78-103.

Zaichkowsky, Judith L (1985), “Measuring the Involvement Construct,” Journal of Consumer Research, pp. 34152.

Zajonc, R. B. (1980). Feeling and thinking: Preferences need no inferences. American Psychologist, 35, 151175.

Banerjee, Bibek; Raghuram, G and Koshy, Abraham (1999). "FoodWorld (C): The Road Ahead,"Working Paper, Ahmedabad: Indian Institute of Management.

Raghuram, G; Banerjee, Bibek; Jain, A K; Koshy,Abraham and Bhatt, Gunjan (1999). Retailscope'99,Retail Sales Data: The Hidden Treasure, Draft Report, Ahmadabad: Indian Institute of Management

Guadagni, Peter M and Little, John D C (1983). "A Logit Model of Brand Choice Calibrated on Scanner Data,"Marketing Science, Vol 2 (Summer),pp 203 - 238.

Wittinik, Dick R; Addona, Michael; Hawkes, William and Porter, John (1988). SCAN*PRO: The Estima-tion, Validation and Use of Promotional Effects Based on Scanner Data, Working Paper, AC Nielsen,Schaumburg, IL.

Berman, B., \& Evans, J. R. (1992). Retail Management: A Strategic Approach (5th ed.). New York: Macmillan.

Darden, W. R., \& JoAnn K. L. S. (1985). The influence of Social Characteristics on Perceived Quality in patronage choice behavior. In J. Jcob \& J. Olson (Eds.), perceived quality (pp. 161-172). Lexington, MA,Lexington Book.

Donovan, R. J., \& Rossiter, J. R. (1982). Store Atmosphere: An environmental psychology approach. Journal of Retailing, 58(2), 34-57. 
Huddleston, P., Ford, I., \& Mahoney, M. (1990). The relationship between importance of retail store attributes and lifestyle of mature female consumers. Journal of Consumer Studies and Home Economics, 14, 7185.http://dx.doi.org/10.1111/j.1470-6431.1990.tb00037.x

Kotler, P. (1973-1974). Atmospherics as a marketing tool. Journal of Retailing, 49(4), 48-55.

Aggarwal, A.2000 “Current Issues in Indian Retailing”.European Retail Digest. 25, 70-71.

Arnold, S. J., Ma, S. and Tigert, D. J. 1978 “A comparative analysis of determinant attributes in retail store selection”. Advances in Consumer Research, 5, 663-67.

Babin, B.J. and Darden, W.R. 1995, “Consumer self-regulation in a retail environment”, Journal of Retailing, 71(1), 47-70.

Baltas G. and Argouslidis, 2007 “Consumer characteristics and demand for store brands” International Journal of Retail \& Distribution Management, 35 (5), 328-41.

Bell, D. R., Teck-Hua Ho, and Christopher S. Tang. 1998 "Determining where to shop: Fixed and variable costs of shopping”. Journal of Marketing Research, 35 (August), 352-69.

Bawa, K. and Ghosh, A. 1999 “A model of household grocery shopping behaviour”.Marketing Letters. 10, (2), 149-60.

Becker, G.S. 1965 “A theory of the allocation of time”. The Economic Journal 75(299) 493-517.

Bellenger, D.N., Robertson, D. H., and Greenberg, B. A. 1977 “Shopping centre patronage motives”, Journal of Retailing. 53(2), 29-38.

Blattberg, R.Buesing,T., Peacock,P., and Sen,S., 1978 “Identifying the deal prone segment”. Journal of Marketing Research 15(3) 369-77.

Buttle, F. 1992 “Shopping motives constructionist perspective”. The Service Industries Journal, 12, (3), 349-67.

Buttle, F., 1985 “Measuring food store image using Kelly’s repertory grid”. The Service Industries Journal. 5(1), 79-89.

Chetthamrongchai, P. and Davies, G. 2000 "Segmenting the market for food shoppers using attitudes to shopping and to time” British Food Journal, 102(2), 81-101.

Forsythe, S.M. and Bailey, A.W. 1996 “Shopping enjoyment, perceived time poverty and time spent shopping”. Clothing and Textiles Research Journal.14, No.1, 185-91.

Hsu M.K., Huang Y. and Swanson Scott 2010 “Grocery store image, travel distance, satisfaction and behavioural intentions”. International Journal of Retail \& Distribution Management, 38 No.2, 115-32.

Huddleston, P., Whipple, J., Mattick, R.N. and Lee S.J 2009 “Customer satisfaction in food retailing: comparing specialty and conventional grocery stores” International Journal of Retail \& Distribution Management, 37, No.1, 63-80.

Li-Wei M. and Hui Z.2004 “The characteristics of supermarket shoppers in Beijing”,International Journal of Retail \& Distribution Management, 32(1), 56-62.

Messinger, P. R., and Narasimhan, C.1997 “A model of retail formats based on consumers”'economizing on hopping time”, Marketing Science, 16(1)

Mulky A. and Nargundkar R., 2003 "Modernization in Indian retailing: managerial and policy perspectives” Udyog Pragati, 27(2), 1-8. 
Paulins V. Ann and Loren V. Geistfled 2003, “The effect of consumer perceptions of store attributes on apparel store preference”. Journal of Fashion Marketing and Management. 7(4), 371- 85.

Peter J. P. and Ryan, J.M. 1976“An investigation of perceived risk at the brand level.Journal of Marketing Research, 13(2), 184-188.

Prasad, C.J.S. and Reddy, D.R. 2007 "A study on role of demographic and psychographic dynamics in food and grocery retailing in India”, Vision - The Journal of Business Perspective, 11, (4), 21-30.

Prasad, C. J. and Aryasri, A. R. 2011 "Effect of shopper attributes on retail format choice behaviour for food and grocery retailing in India”. International Journal of Retail \& Distribution Management, 39 (1) 68-86.

Parikh, D.2005 "Measuring retail service quality: an empirical study in a developing country”.South Asian Journal of Management, 12, 2, 43.

Sengupta, A.2008. "Emergence of modern Indian retail: an historical perspective". International Journal of Retail \& Distribution Management. 36 (9) 689-700.

Srivastava, R.K. 2008 “Changing retail scene in India”, International Journal of Retail \& Distribution Management, 36 (9),714- 21.

South, S.J. and Spitze, G.1994, "Housework in marital and non-marital households", American Sociological Review, 59, June, 327-47.

Steenkamp, Jan-Benedict E.M. 2001“The role of national culture in international marketing research”. International Marketing Review. 18(1) 30-44. 


\section{Appendix}

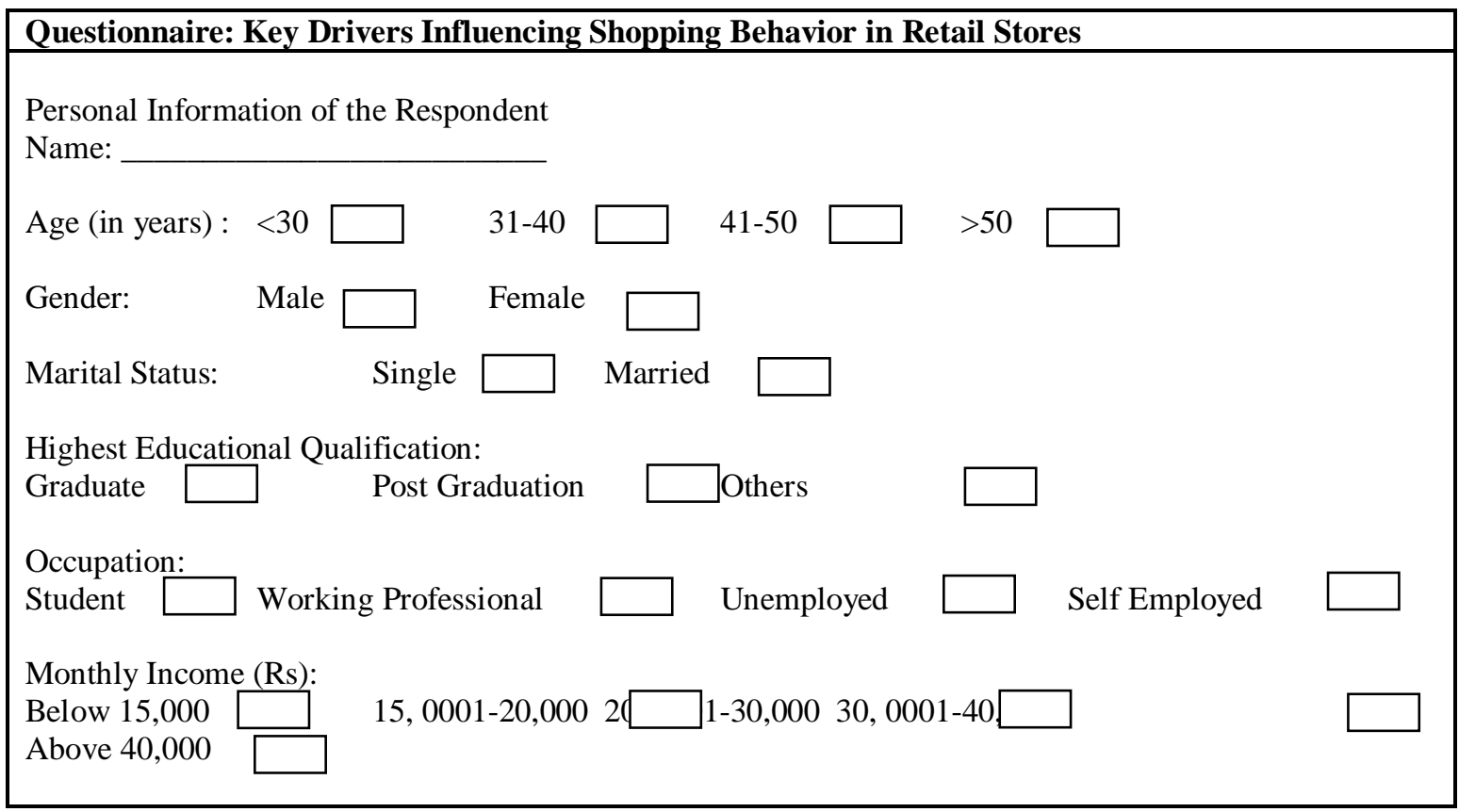

Do you disagree or agree with the following statements?

\begin{tabular}{|c|c|c|c|c|c|c|}
\hline 1. & Extending opening hours of the store can enhance the reputation of the store & 1 & 2 & 3 & 4 & 5 \\
\hline 2. & Location of store is convenient with good network of transportation & 1 & 2 & 3 & 4 & 5 \\
\hline 3. & Compared to other stores the prices of this store are low & 1 & 2 & 3 & 4 & 5 \\
\hline 4. & Is the merchandise available in the store is of good quality & 1 & 2 & 3 & 4 & 5 \\
\hline 5. & Do you prefer to shop in stores where the employees are friendly and pleasant & 1 & 2 & 3 & 4 & 5 \\
\hline 6. & Do you prefer to shop in stores where employees of have product knowledge & 1 & 2 & 3 & 4 & 5 \\
\hline 7. & $\begin{array}{l}\text { Do you prefer to shop in stores where merchandise display and assortment is good with } \\
\text { enough space between display area }\end{array}$ & 1 & 2 & 3 & 4 & 5 \\
\hline 8. & The store is clean and tidy & 1 & 2 & 3 & 4 & 5 \\
\hline 9. & The special offers that are available are well advertised & 1 & 2 & 3 & 4 & 5 \\
\hline 10. & The return policy of the store is fair & 1 & 2 & 3 & 4 & 5 \\
\hline 11. & Your Shopping is influenced by the Store atmospherics and the decor of the store & 1 & 2 & 3 & 4 & 5 \\
\hline 12. & Do you prefer to shop in stores where there are sufficient checkouts & 1 & 2 & 3 & 4 & 5 \\
\hline Note & $\begin{array}{l}\text {-Stongly Disagree } \\
\text { 5- Strongly Agree }\end{array}$ & & & & & \\
\hline
\end{tabular}

